\title{
Assessment of safety and efficacy of lamotrigine over the course of I-year observation in Japanese patients with bipolar disorder: post-marketing surveillance study report [Corrigendum]
}

\author{
Terao T, Ishida A, Kimura T, Yoshida M, Hara T. Neurop- \\ sychiatr Dis Treat. 2017;13:1441-1448. \\ On page 1443, Results section, Patient disposition subheading, \\ Figure S1, 'Excluded from HAM-D analysis set ${ }^{\mathrm{C}} 69$ ' should \\ have been 'Excluded from HAM-D analysis set ${ }^{\mathrm{C}} 269$ '.
}

\section{Publish your work in this journal}

Neuropsychiatric Disease and Treatment is an international, peerreviewed journal of clinical therapeutics and pharmacology focusing on concise rapid reporting of clinical or pre-clinical studies on a range of neuropsychiatric and neurological disorders. This journa is indexed on PubMed Central, the 'PsycINFO' database and CAS, and is the official journal of The International Neuropsychiatric Association (INA). The manuscript management system is completely online and includes a very quick and fair peer-review system, which is all easy to use. Visit http://www.dovepress.com/testimonials.php to read real quotes from published authors. 